\title{
MEDIA AND DEMOCRACY: FOUR PARADIGMATIC VIEWS
}

Kavous Ardalan

School of Management, Marist College, Poughkeepsie, New York 12601-1387, USA

E-Mail: Kavous.Ardalan@Marist.Edu

Any explanation of media and democracy is based on a worldview. The premise of this paper is that any worldview can be associated with one of the four broad paradigms: functionalist, interpretive, radical humanist, and radical structuralist. This paper takes the case of media and democracy and discusses it from the four different viewpoints. It emphasizes that the four views expressed are equally scientific and informative; they look at the phenomenon from their specific paradigmatic viewpoint; and together they provide a much broader, deeper, and balanced understanding of the phenomenon under consideration.

These different perspectives should be regarded as polar ideal types. The work of certain authors helps to define the logically coherent form of a certain polar ideal type. But, the work of many authors who share more than one perspective is located between the poles of the spectrum defined by the polar ideal types. The purpose of this paper is not to put people into boxes. It is rather to recommend that a satisfactory perspective may draw upon several of the ideal types.

Social theory can usefully be conceived in terms of four key paradigms: functionalist, interpretive, radical humanist, and radical structuralist. The four paradigms are founded upon different assumptions about the nature of social science and the nature of society. Each generates theories, concepts, and analytical tools which are different from those of other paradigms.

In order to understand a new paradigm, theorists should be fully aware of assumptions upon which their own paradigm is based. Moreover, to understand a new paradigm one has to explore it from within, since the concepts in one paradigm cannot easily be interpreted in terms of those of another. No attempt should be made to criticize or evaluate a paradigm from the outside. This is self-defeating since it is based on a separate paradigm. All four paradigms can be easily criticized and ruined in this way.

These four paradigms are of paramount importance to any scientist, because the process of learning about a favored paradigm is also the process of learning what that paradigm is not. The knowledge of paradigms makes scientists aware of the boundaries within which they approach their subject. Each of the four paradigms implies a different way of social theorizing.

Each theory can be related to one of the four broad worldviews. These adhere to different sets of fundamental assumptions about; the nature of science (i.e., the subjective-objective dimension), and the nature of society (i.e., the dimension of regulation-radical change), as in Exhibit 1.

Assumptions related to the nature of science are assumptions with respect to ontology, epistemology, human nature, and methodology.

The assumptions about ontology are assumptions regarding the very essence of the phenomenon under investigation. That is, to what extent the phenomenon is objective and external to the individual or it is subjective and the product of individual's mind.

The assumptions about epistemology are assumptions about the nature of knowledge about how one might go about understanding the world, and communicate such knowledge to others. That is, what constitutes knowledge and to what extent it is something which can be acquired or it is something which has to be personally experienced.

The assumptions about human nature are concerned with human nature and, in particular, the relationship between individuals and their environment, which is the object and subject of 
social sciences. That is, to what extent human beings and their experiences are the products of their environment or human beings are creators of their environment.

The assumptions about methodology are related to the way in which one attempts to investigate and obtain knowledge about the social world. That is, to what extent the methodology treats the social world as being real hard and external to the individual or it is as being of a much softer, personal and more subjective quality. In the former, the focus is on the universal relationship among elements of the phenomenon, whereas in the latter, the focus is on the understanding of the way in which the individual creates, modifies, and interprets the situation which is experienced.

The assumptions related to the nature of society are concerned with the extent of regulation of the society or radical change in the society.

Sociology of regulation provides explanation of society based on the assumption of its unity and cohesiveness. It focuses on the need to understand and explain why society tends to hold together rather than fall apart.

Sociology of radical change provides explanation of society based on the assumption of its deep-seated structural conflict, modes of domination, and structural contradiction. It focuses on the deprivation of human beings, both material and psychic, and it looks towards alternatives rather than the acceptance of status quo.

The subjective-objective dimension and the regulation-radical change dimension together define four paradigms, each of which share common fundamental assumptions about the nature of social science and the nature of society. Each paradigm has a fundamentally unique perspective for the analysis of social phenomena.

The aim of this paper is not so much to create a new piece of puzzle as it is to fit the existing pieces of puzzle together in order to make sense of it. Sections II to V, first, each lays down the foundation by discussing one of the four paradigms. Subsequently, each examines media and democracy from the point of view of the respective paradigm. Section VI concludes the paper.

\section{References}

1. Abramson, Jeffrey B., Arterton, F. Christopher, and Orren, Gary R., 1998, The Electronic Commonwealth: The Impact of New Media Technologies on Democratic Politics, New York, New York: Basic Books.

2. Altheide, David L., 1974, Creating Reality: How TV News Distorts Events, Beverly Hills, California: Sage Publications.

3. Ardalan, Kavous, 2008, On the Role of Paradigms in Finance, Aldershot, Hampshire, U.K.: Ashgate Publishing Limited, and Burlington, Vermont, U.S.A.: Ashgate Publishing Company.

4. Bettner, M.S., Robinson C., and McGoun E., 1994, "The Case for Qualitative Research in Finance," International Review of Financial Analysis, 3:1, pp. 1-18.

5. Burrell, Gibson and Morgan, Gareth, 1979, Sociological Paradigms and Organizational Analysis, Hants, England: Gower Publishing Company Limited.

6. Cairncross, Frances, 1997, The Death of Distance: How the Communications Revolution Will Change Our Lives, Boston, Massachusetts: Harvard Business School Press.

7. Chomsky, Noam, 1989, Necessary Illusions: Thought Control in Democratic Societies, Boston, Massachusetts: South End Press. 
8. Elliott, Philip, 1974, "Selection and Communication in a Television Production: A Case Study," in Tuchman, Gaye, (ed.), The TV Establishment: Programming for Power and Profit, Englewood Cliffs, New Jersey: Prentice-Hall, Chapter 4, pp. 72-90.

9. Epstein, Edward Jay, 1973, News from Nowhere: Television and the News, New York, New York: Random House.

10. Gans, Herbert, 1974, Popular Culture and High Culture: An Analysis and Evaluation of Taste, New York, New York: Basic Books.

11. Herman, Edward S. and Chomsky, Noam, 1988, Manufacturing Consent: The Political Economy of the Mass Media, New York, New York: Pantheon Books.

12. Herman, Edward S. and McChesney, Robert W., (2004), The Global Media: The New Missionaries of Corporate Capitalism, London, England: Continuum.

13. Hirsch, Paul and Newcomb, Horace, 1987, "Television as a Cultural Forum," in Newcomb, Horace, (ed.), Television: The Critical View, New York, New York: Oxford University Press, pp. $455-470$.

14. Kelley, David and Downey, Roger, 1990, "Liberalism and Free Speech," in Lichtenberg, Judith, (ed.), Democracy and the Mass Media, Cambridge, UK: Cambridge University Press, Chapter 2, pp. 66-101.

15. Kellner, Douglas, 1990, Television and the Crisis of Democracy, Boulder, Colorado: Westview Press.

16. Leys, Colin, 1999, "The Public Sphere and the Media: Market Supremacy versus Democracy," in Panitch, Leo and Leys, Colin, (eds.), Global Capitalism versus Democracy: Socialist Register 1999, New York, New York: Monthly Review Press, pp. 314-335.

17. Mayer-Schonberger, Viktor and Hurley, Deborah, 2000, "Globalization and Communication," in Nye, Joseph S., (ed.), Governance in a Globalizing World, Washington, DC: Brookings Institution Press, Chapter 6, pp. 135-154.

18. McChesney, Robert W., 1997, Corporate Media and the Threat to Democracy, New York, New York: Seven Stories Press.

19. McChesney, Robert W., Wood, Ellen Meiksins, and Foster, John Bellamy, (eds.), 1998, Capitalism and the Information Age: The Political Economy of the Global Communication Revolution,

20. Parenti, Michael, 1993, Inventing Reality: The Politics of News Media, New York, New York: St. Martin's Press.

21. Rapping, Elayne, 1987, The Looking Glass World of Nonfiction TV, Boston, Massachusetts: South End Press.

22. Schiller, Herbert I., 1973, The Mind Managers, Boston, Massachusetts: Beacon Press.

23. Schiller, Herbert I., 1976, Communication and Cultural Domination, White Plains, New York: International Arts and Sciences Press, Inc.

24. Schiller, Herbert I., 1989, Culture, Inc: The Corporate Takeover of Public Expression, New York, New York: Oxford University Press.

25. Skornia, Harry J., 1968, Television and the News: A Critical Appraisal, Palo Alto, California: Pacific Books. 